Philip R. Bilancia

Dictionary of Chinese Law and Government, Chinese-English, Stanford University Press, 1981, pp. XV, 822, \$45.

Dealing with the political language of the People's Republic of China has frequently taxed the skills of Western students, and the consequent need for translation aids has produced a number of widely different bilingual dictionaries, compiled outside China, on political phrases, ${ }^{1}$ international relations ${ }^{2}$ and general political and economic vocabulary. ${ }^{3}$ Specifically legal and government-affairs terminology had not, however, been the main theme of any such dictionaries, and until the publication of Mr Bilancia's book no serious lexicographic effort had been made in this field. ${ }^{4}$

This new lexicon is impressive by its mere scope, by far surpassing the other specialised bilingual reference books now on the market. ${ }^{5}$ It includes more than 25,000 Chinese terms, about 15,000 examples of usage and over 30,000 cross-references. The material is drawn almost entirely from Communist Chinese sources, spanning the period from 1939 to 1977. The printing is excellent and bold type for the transliterated entries and sub-entries has been employed to good effect. An important single character usually forms a head entry, giving its topical meanings. The author has sensibly dispensed whith the custom of many Chinese lexicographers to arrange entries strictly by their initial character. Thus the head entry also provides relevant compounds and examples of usage where the character in question does not come at the beginning. Head entries (if any) are followed by others, also laid out as main entries in the dictionary body but giving compounds of the head entry's character.

The dictionary proper is preceded by explanations on its use. At the end we find a radical index based on 211 of the Kang $\mathrm{Xi}$ radicals and a conversion table for ten different transliteration systems, alphabetised according to Hanyu Pinyin, now officially used in the PRC and by most Western news media.

The author does not explain why he chose to arrange the entries by the, now largely outdated, Wade-Giles system of transliteration. He has, moreover, introduced a further unfamiliarity for those accustomed to Wade-Giles, by alphabetising unaspirated and aspirated initials in separate subdivisions. In addition, he has replaced the superscript numbers of Wade-Giles by the diacritical marks of Hanyu Pinyin.

1 e. g., Lau Yeefui et al., Glossary of Chinese Political Phrases, Hong Kong: Union Research Institute, 1977. This glossary centres on longer political catchphrases and slogans and provides detailed decumentation of their historical appearance in the PRC media.

2 e. g., S. Jascheck, Wörterbuch der internationalen Beziehungen, Chinesisch-Deutsch, Bonn, 1976, containing a wealth of official titles and names of international organisations, diplomatic terminology, etc.

3 e. g., H. Martin/T C Liao, Chinesisch-deutscher Wortschatz, Politik und Wirtschaft der VR China, Berlin etc: Langenscheid, 1977, covering a wide variety of political, economic and legal terms.

4 There have existed for several years various "law dictionaries", published in Taiwan, but their renderings all too of ten beclouded the real meaning of (Republican) Chinese legal terms, not least by facile equation of Continental-inspired Republican Chinese concepts and those of Anglo-American Laws.

5 e. g., all those given in notes $1-3$, above 
Questions of pronounciation were mostly referred to rather old (Kou-yü tzu-tien) of foreign (Oshanin, McGraw-Hill) dictionaries instead of, e. g., the 1965 Xiandai Hanyu Cidian, which has been available outside China at least since 1977, in a Hong Kong reprint by Commercial Press there. This would have helped to avoid, for instance, giving 'qîyèr (undertaking, enterprise) as 'qiyèr.

Selection is one of the obvious difficulties for any compiler of specialised dictionaries, and it clearly also plagued the author, who opted for including such patently non-legal and non-administrative terms as, e. g., 'chuishiyuan' (a cook) or 'weifeng' (a breeze).

The translation of legal terms is always a demanding task. When the legal systems of the languages involved differ merkedly these problems are compounded, and pitfalls multiply. Witness such specious equivalents as the English-law rexecutor' and the German 'Testamentsvollstrecker'. Bilancia has commendably pointed out where technical appellations in Chinese only refer to foreign, or Chinese, legal concepts and institutions, as the case may be. ${ }^{6}$ Many words whose meaning would have been difficult to compress into a single English term are explicated more fully.?

Only continued use will reveal the quality of this new dictionary. Its size rules out any extended examination of individual translation for the purpose of a review. Instead I took a closer look at the terminology of several subjects of likely interest to the general user, particularly the international law of the sea, carriage of goods by sea, the conflict of laws, and criminal law.

A number of important terms of the international law of the sea have not been included: 'zhuanshu jingjiqur (exclusive economic zone), 'dalubianyuan' (continental slope, 'fangbian chuanqir (flags of convenience) ${ }^{8}$ The common term bilianqu (for scontiguous zone') is omitted in favour of the much less familiar linjie haimian ( p. 425). The explanation (p.748) of 'wuhai tongguo (innocent passage), as the "right of innocent passage (for a ship through an international waterway)", entirely misses the point of that doctrine: Passage is indeed through waters under the national jurisdiction of the coastal state. ${ }^{9}$

A rqingjie tidan' (clean bill of lading) is certainly not, as the author leads us to believe (p. 155), one distinguished by its legibility. ${ }^{10}$ For 'paoqir (p. 518) the general average meaning of 'jettison is not given. ${ }^{11}$

A 'zhongcai caipan xieding' (arbitration agreement, compromis) is not (p. 122) necessarily concerned with international arbitration only. ${ }^{12}$

$6 \mathrm{cf}$ the indications in the entries 'p'eishen' et seq., p 519

7 cf 'tien', p 632

8 All of which can be found in the recently published Chinese law dictionary, Faxue Cidian, Shanghai: Cishu chubanshe, 1980 (hereinafter cited as FXCD).

9 see the precise definition in FXCD, p 66

10 for a correct definition, see FXCD, p 648

11 cf Wang Enshao, Gongtong Haisun, Peking, 1979, pp 26 et seq.

12 cf FXCD, p 265 
The private international law terms 'falü chongtur (conflict of laws), 'fayuandifar (lex fori) and shewai minshi falüguanxi' (the Chinese equivalent for' (civil) cases with a foreign element') are not given. ${ }^{13}$, Guoji sifar (private international law) is misleadingly explained (p. 380) as the "customary law of international transactions and conflicts of law", thus blurring, among others, the important aspect of its strictly municipal character. ${ }^{14}$

In one case, certain conceptual distinctions of Chinese penal law have apparently not been appreciated by the translator: 'fanzui zhijie keti (immediate object of a crime) and 'fanzui duixiang' (target of a crime) are not at all the same, as the author surmises (p. 205). The former denotes the injured right, legally created and protected, as manifested in the individual victim or damaged property. In such 'immediate objects the injurious consequences of a criminal act are embodied. The latter denotes the object of criminal behaviour to which such behaviour causes injury or damage. Distinct from these two are the syiban fanzui ketic (objects of a crime generally conceived), correctly defined by the author (p. 205) as the rights and social relationship protected by the criminal law. ${ }^{15}$

This threefold differentiation is not meaningless: The general object of a crime, say, bodily integrity of others, may be violated by someone firing a blank charge at a person in the belief to be using live ammunition and with intention to kill. No injury to an rimmediate object of a crimer would have to result to make this act a punishable offence. Likewise, no 'target' would in fact have to exist if only the person shooting had believed to be firing at another person. Also, resisting a government officer in the course of his official duties would make the individual officer the 'target' of such resistance. The immediate object ' of the of fence, however, would be the legally protected execution of a certain official act, say, a search of premises or an arrest. ${ }^{16}$

Under miscellaneous topics considered I could not find, among others: "sifa huomianquan (diplomatic immunity from process), bili daibiaozhi (proportional representation), 'wudai' (the 'five generations' in family law), 'Ouzhou gongtongti' (European Communities) and 'Shijie Yinhang' (the World Bank).

A somewhat ingenuously noncommittal definition has been given for the so-called Great Proletarian Cultural Revolution (p. 748). Earlier dictionaries of Chinese political language showed more skepticism by, for instance, providing several Chinese comments on the supposed origin and import of that event. ${ }^{17}$

Mr Bilancia has collected in his lexicon an great deal of material, and any student of modern China will be grateful for having this vast mass of data put at his disposal in a systematic

13 for all these, see FXCD, pp 466, 469, 599

14 cf the succinct definition in FXCD, p 403

15 for a fuller presentation, see Zhonghua Renmin Gongheguo Xingfa Zongze Jiangyi, Peking: Qunzhong chubanshe, 1980, pp 106 et seq.

16 cf Zongze Jiangyi (prec note), pp 110 et seq.; E. Schmidhäuser, Strafrecht, Allgemeiner Teil, 2nd ed, Tübingen: Mohr (Siebeck), 1975, pp 36-41

17 Glossary... (note 1, above), under 'wuchanjieji wenhua dageming' 
fashion. The sheer dimensions of this compilation and the inaccuracies pointed out should, on the other hand, serve to encourage China specialists from various disciplines to combine their efforts in future similar projects. No single compiler is likely to command the expertise necessary for lucid and well-thought-out translations and explanations of all the terminology assembled between the convers of this, on the whole, remarkable dictionary.

Wolfgang Keßler

\section{Jeanette Greenfield}

China and the Law of the Sea, Air, and Environment

Sijthoff \& Noordhoff, Alphen aan den Rijn u. Germantown, Maryland - USA, 1979, US $\$ 32.50$

Seit der Aufnahme der Volksrepublik China (VRC) in die Vereinten Nationen im Oktober 1971 ist die Haltung Chinas hinsichtlich ínternational-rechtlicher Fragen als wichtiger Faktor der Fortbildung des Völkerrechts für die übrigen Mitglieder der Staatengemeinschaft von wachsender Bedeutung. Ein u. a. auf den Gebieten des See-, Luft- und Umweltrechts diesbezüglich bestehendes Informationsdefizit will das vorliegende Buch von Jeanette Greenfield abbauen.

In ihrer Untersuchung wertet die Autorin neben der nur spärlich vorhandenen Literatur Stellungnahmen der VRC, insbesondere in Ausschüssen und Organen der Vereinten Nationen, völkerrechtliche Verträge, an denen sie beteiligt ist, einseitige Deklarationen sowie Veröffentlichungen in der chinesischen Presse als amtlichen Publikationsorganen aus. Die schwer auffindbaren Originärquellen, z. T. auch nationale chinesische Rechtsnormen, sind teilweise in einem umfangreichen Anhang (93 Seiten) abgedruckt, u. a. die Declaration on China's Territorial Sea v. 4. 9. 1958, Communist China Regulations on Rivers and Ports, PRC Regulations for Waterway and Cargo Transportation, ferner verschiedene von der chinesischen Delegation im "Committee on the peaceful use of the sea-bed and the ocean floor beyond the limitis of national jurisdiction" eingebrachte Arbeitspapiere.

Der Leser, der eine klare Aussage erwartet, inwieweit die chinesische Rechtsauffassung mit universellem Völkerrecht übereinstimmt oder davon abweicht, wird jedoch enttäuscht. Es gelingt der Autorin nicht, die zahlreichen Einzeläußerungen, die nach ihrem eigenen Resumé z. T. recht widersprüchlich sind, in übersichtlicher Form zu ordnen und darzustellen. Ein Gliederungssystem innerhalb der einzelnen Kapitel sucht man vergeblich. Die durch die Voranstellung eines kurzen Abrisses chinesischer Rechtsgeschichte, verbunden mit dem Hinweis auf die Verknüpfung von Recht und Philosophie, geweckte Erwartung, in den folgenden Artikeln eine Bezugnahme, bzw. Erklärungsversuche oder Erläuterungen zu finden, wie sich die völkerrechtlichen Grundtendenzen der VRC aus 